\title{
Pinanga lepidota (Arecaceae: Arecoideae), a new record for the Philippines from Palawan Island
}

\author{
Edwino S. Fernando ${ }^{1,4,5}$, Eugene L.R. Logatoc ${ }^{2}$, Pastor L. Malabrigo Jr. ${ }^{1,4}$, and Jiro T. Adorador ${ }^{3}$
}

\begin{abstract}
Pinanga lepidota (Arecaceae), previously known only from Borneo, is reported here as a new record for the Philippines from Palawan Island. A key to the identification of similar species of Pinanga in the Philippines is provided, including brief notes on Bornean Arecaceae elements in Palawan.
\end{abstract}

Keywords: Mt Mantalingahan, Palmae, palms, Pinanga

\section{Introduction}

Pinanga Blume includes acaulescent or erect, diminutive or robust forest undergrowth palms that occur from sea level up to ca. $2800 \mathrm{~m}$ elevation (Dransfield et al. 2008). The genus name is the Latinized form of the Malay vernacular name pinang, often applied to the betel nut palm, Areca catechu L., and various other species of the genera Areca L., Pinanga, and Nenga H.Wendl. \& Drude (Dransfield et al. 2008). Pinanga occurs in tropical and subtropical Asia to the northwest Pacific, from the Himalayas and south China to New Guinea (Dransfield et al. 2008, Govaerts et al. 2020). Currently, there are about 142 species in the genus (Govaerts et al. 2020), with the greatest diversity occurring west of Wallace's Line. At least 40 species occur in Borneo, 26 species in Malay Peninsula, only seven species in Sulawesi, and just one species at its eastern limit in

\footnotetext{
${ }^{1}$ Department of Forest Biological Sciences, College of Forestry and Natural Resources, University of the Philippines - Los Baños, College, 4031 Laguna, Philippines;

${ }^{2}$ Graduate School, University of the Philippines - Los Baños, College, 4031 Laguna, Philippines

${ }^{3}$ Plant Biology Division, Institute of Biological Sciences, College of Arts and Sciences, University of the Philippines - Los Baños, College, 4031 Laguna, Philippines

${ }^{4}$ Museum of Natural History, University of the Philippines - Los

Baños, College, 4031 Laguna, Philippines

${ }^{5}$ Institute of Biology, College of Science, University of the Philippines

- Diliman, 1101 Quezon City, Philippines

*Corresponding email: esfernando@up.edu.ph

Date Submitted: 16 June 2020

Date Accepted: 11 September 2020
}

New Guinea (Govaerts et al. 2020). In the Philippines, 20 species were earlier listed by Beccari (1919) and Merrill (1922); six species have since been added to this list (Fernando 1988, 1994, Adorador et al. 2020).

Our continuing studies on the palms of the Philippine Islands have revealed the presence of Pinanga lepidota Rendle on the lower slopes of Mt Mantalingahan near the southern end of Palawan Island, approximately $220 \mathrm{~km}$ from Sabah on the northeastern tip of Borneo. There is just one other species of Pinanga, P. curranii Becc., that occurs in Palawan (Fernando 1988, 1990a). Pinanga lepidota, thus becomes only the second species of Pinanga in Palawan, bringing to a total of 27 species for the whole Philippines.

Pinanga lepidota is a beautiful slender, clustering palm first described by Alfred Barton Rendle (1901) based on a specimen collected by Charles Hose in April 1895 in the Baram District of Sarawak, Borneo. Outside of Sarawak, this species has also been collected and recorded in other northern parts of Borneo (Dransfield 1980b), e.g. Brunei, Sabah, and Kalimantan Timur.

\section{Materials and Methods}

In January 2020 during a botanical survey on Mt Mantalingahan in the south of Palawan Island, Philippines, we documented and collected a diminutive, clustering undergrowth species of Pinanga. We subsequently compared our field notes and specimen collection with herbarium specimens at Philippine herbaria, namely, LBC, PNH, and PUH and reviewed relevant literature. On determining the collection to be that of Pinanga lepidota Rendle, hitherto known only from Borneo, we then examined an isotype of this species at $\mathrm{PNH}$ and digital image of 
the holotype at BM, and other specimens at K, L, and NY for comparison. Herbarium acronyms follow Thiers (2018continuously updated). Here we present our account of the occurrence of this species in Palawan, including a diagnostic description, and a key to the identification of similar species of Pinanga in the Philippines. We also provide brief notes on Bornean palm elements in Palawan.

\section{Taxonomic Treatment}

Pinanga lepidota Rendle, J. Bot. 39: 177 (1901); Merrill, Bibl. Enum. Bornean Plts. 84 (1921); Dransfield, Kew Bull. 34: 774 (1980). Figs. 1-2.

Type: BORNEO, Sarawak, Baram, April 1895, C. Hose 702 (holotype BM [BM001040833], image seen; isotype PNH! [PNH-32211]).

Pinanga baramensis Furtado, Feddes Repert. 35: 277 (1934). Type: BORNEO, Sarawak, Baram, J. Hewitt s.n. in Sept. 1907 (holotype K [K000207915], image seen).

Pinanga barramensis Becc. ex Martelli, Atti Soc. Tosc. Sci. Nat. Res. Pisa. Mem. 44: 124 (1934). Type: BORNEO, Sarawak, Baram, 20 July 1908, F.W. Foxworthy 511 (lectotype FI, n.v.; isolectotype PNH! [PNH-26144]).

Slender, clustering, pleonanthic, undergrowth palm, to 1.5 $\mathrm{m}$ tall. Stems to $c a .1 \mathrm{~cm}$ diam.; internodes $c a .5-10 \mathrm{~cm}$ long; crownshaft elongate, tubular, $27-40 \mathrm{~cm}$ long. Leaves to 5 in crown; leaf sheath $15 \mathrm{~cm}$ long, covered with reddish-brown scaly indumentum; petiole up to $16 \mathrm{~cm}$ long; lamina sometimes entire, except for deep apical split, inversely sagittate and bifid, or segmented up to $64 \mathrm{~cm}$ long and $24 \mathrm{~cm}$ at its widest point near the apex, the adaxial surface of lamina often glossy, the abaxial side paler, leaf segments asymmetrical, up to 2 on each side of the rachis, basal segments 4-6-costate, up to $21 \times 5.8$ $\mathrm{cm}$, apical segments 9-10-costate, $24 \mathrm{~cm}$ long (mid-section to apex), fused up to $16 \mathrm{~cm}$ at the base. Inflorescence infrafoliar, an unbranched, simple spadix, $c a$. 7-8 cm long, often erect; staminate and pistillate flowers not known. Fruits ovoid, 10-12 $\mathrm{mm}$ long, 4-5 $\mathrm{mm}$ wide, light yellow to yellow orange throughout, arranged distichously along the rachilla, up to $9 \mathrm{~mm}$ apart, fruiting perianth $5 \times 3 \mathrm{~mm}$, slightly broadened at the mouth.

Distribution, habitat, and ecology: This species is known from Borneo (Sarawak, Sabah, Brunei, and Kalimantan Timur) and the Philippines (Palawan). In Borneo, it has been recorded up to $1500 \mathrm{~m}$ elevation on various types of habitats, including hill dipterocarp, lower montane, ultramafic, and heath forests (see representative Bornean specimens examined). The habitat on Mt Mantalingahan in Palawan where Pinanga lepidota was discovered was at $c a$. $600 \mathrm{~m}$ elevation in a dipterocarp forest with canopy of 20-25 m and tree emergents to $35 \mathrm{~m}$ tall. The species is rather uncommon in the area. The mottled-leaved $P$. curranii also occurs here, including Areca vidaliana Becc., Orania paraguanensis Becc. and several species of rattans.

Vernacular name: Pisa-pisa. This vernacular name is also applied to Areca vidaliana.

Specimens examined: PHILIPPINES. Palawan Island, Municipality of Rizal, Mt Mantalingahan (west side), Barangay Ransang, Sitio Balen-balen, Baluing, $8^{\circ} 48^{\prime} 45.72$ ” N, $117^{\circ}$ 36'08.1" E, dipterocarp forest, $610 \mathrm{~m}$ elev., 20 June 2007, N.A. Bartolome 4965 (PUH!), along trail from Baluing to Kebgen, ca. $600 \mathrm{~m}$ elev., 10 January 2020, E.L.R. Logatoc 20-0156 (LBC!).

Representative Bornean specimens examined for comparison: SARAWAK: Baram District, April 1895, C. Hose 702 (holotype BM [BM001040833] image seen; isotype PNH! [PNH-32211]), Sept 1907, J. Hewitt s.n. (K [K000207915]), image seen, holotype of Pinanga baramensis Furtado], Claudetown, Baram, 20 July 1908, F.W. Foxworthy 511 (PNH! [PNH-26144], isotype of Pinanga barramensis Becc. ex Martelli); Narudi Forest Reserve, ca. 152 m elev., 05 Feb 1966, W.L. Chew 979 (L [L0616044], image seen); Bukit Penarih, Balingian, heath forest, $10 \mathrm{~m}$ elev., 18 Oct 1963, P.S. Ashton S.19443 (L [L0616049], image seen); 4th Division, Gunung Mulu National Park, between Sg. Medalam and Lobang Cina, kerangas forest, $100 \mathrm{~m}$ elev., 15 Oct 1977, J. Dransfield 5335 (L [L0616042], image seen); 5th Division, Gunung Pagon, Limbang, sub-montane mossy forest, $1500 \mathrm{~m}$ elev., 15 Aug 1984, D. Awa \& B. Lee S.47890 (NY [NY02325892], image seen). BRUNEI: Temburong, NE of Gunung Retak, $1125 \mathrm{~m}$ elev., 10 March 1991, R.J. Johns 6591 (L [L0616051], image seen); Batu Melintang to Batu Patam, near the Sarawak border, 1-180 m elev., 03 Jan 1989, E.F. De Vogel 8876 (L [L1407869], image seen). SABAH: Penampang District, Crocker Range, montane dipterocarp forest, 1000-1050 m elev., 18 March 1984, J.H. Beaman 8970 (L [L0616065], image seen); Ranau District, Bukit Ampuan, ridgetop, hill dipterocarp forest on ultrabasic rock, $700 \mathrm{~m}$ elev., 31 Aug 1979, J. Dransfield et al. 5581 (L [L0616040], image seen); Kinabalu, Penibukan, $1000 \mathrm{~m}$ elev., 12 March 1970, H.P. Nooteboom \& Aban 1571 (L [L1407885], image seen). KALIMANTAN TIMUR: Between Long Bawan and Panado, hill forest on sandstone, $1400 \mathrm{~m}$ elev., 09 July 1981, R. Geesink 8996 (L [L1407902], image seen). 


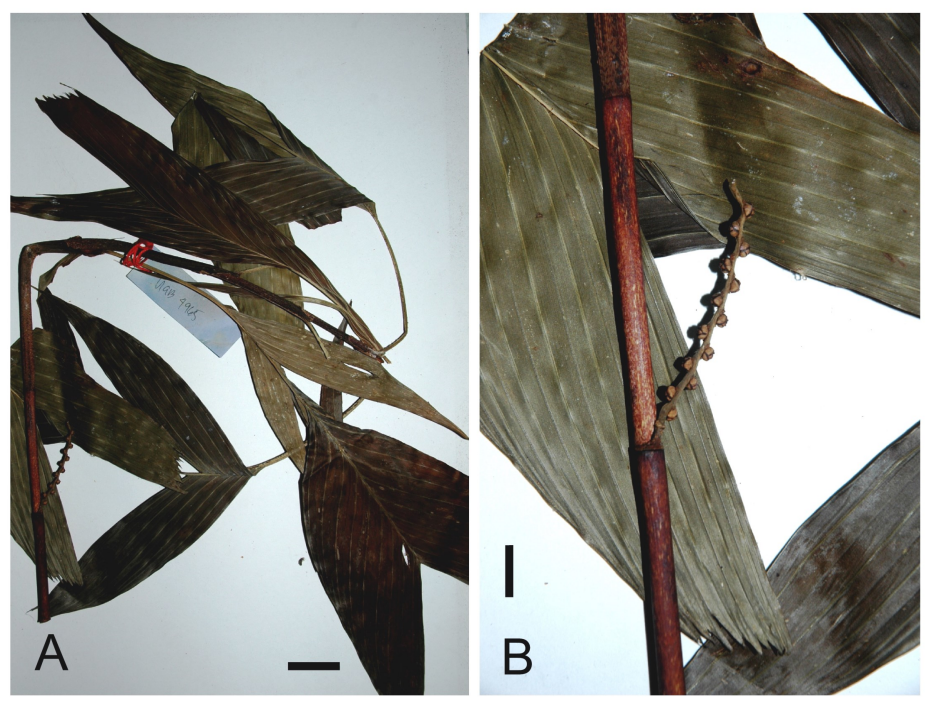

Figure 1. Herbarium specimens of Pinanga lepidota collected from $\mathrm{Mt}$ Mantalingahan, Palawan, 20 June 2007, N.A. Bartolome 4965 (PUH). A Specimen showing dissected leaves; B Simple, unbranched spadix. Scale bars $\mathrm{A}=4 \mathrm{~cm} ; \mathrm{B}=1.5 \mathrm{~cm}$. Photos by Leonard L. Co

Notes: The first specimens of this species collected in Palawan were from Mt Mantalingahan at $610 \mathrm{~m}$ elevation by Mr Nestor A. Bartolome (Fig. 1) during a botanical survey in June 2007 by Conservation International - Philippines as part of a preparatory phase towards formal declaration of the mountain as a protected area in 2009 (Matias \& Tabangay 2014). Our recent collection of this species was from the same mountain at nearly the same elevation (Fig. 2). Although the type specimen (C. Hose 702, BM001040833) from Borneo has leaves with a large entire terminal portion and two small basal leaflets, leaf dissection in this species is regarded as variable, and in Borneo can range from entire leaves to leaves with 3-4 leaf segments on each side of the rachis (Dransfield 1980b). The isotype material in PNH (PNH-32211) has two leaves, each with two segments on each side of the rachis. Pinanga lepidota in Palawan also shows both entire and dissected leaves (Figs. 1-2). The tallest stems among a clump produce leaves with up to just two leaf segments, while leaves near the base are typically entire-bifid (Fig. 1A). Fruits of the collection from Palawan (E.L.R. Logatoc 20-156) have yellow, broad-conical apex (Fig. $2 \mathrm{C})$ which is slightly different from Bornean specimens that typically have fruits with greenish narrow-conical apex.

Among the Philippine species of Pinanga, P. lepidota belongs in the 'Modesta group' (Adorador et al. 2020) characterized by solitary or clustering habit, slender stems, often less than $2 \mathrm{~cm}$ thick, where it can be identified close to Pinanga geonomiformis Becc. using the modified key below.

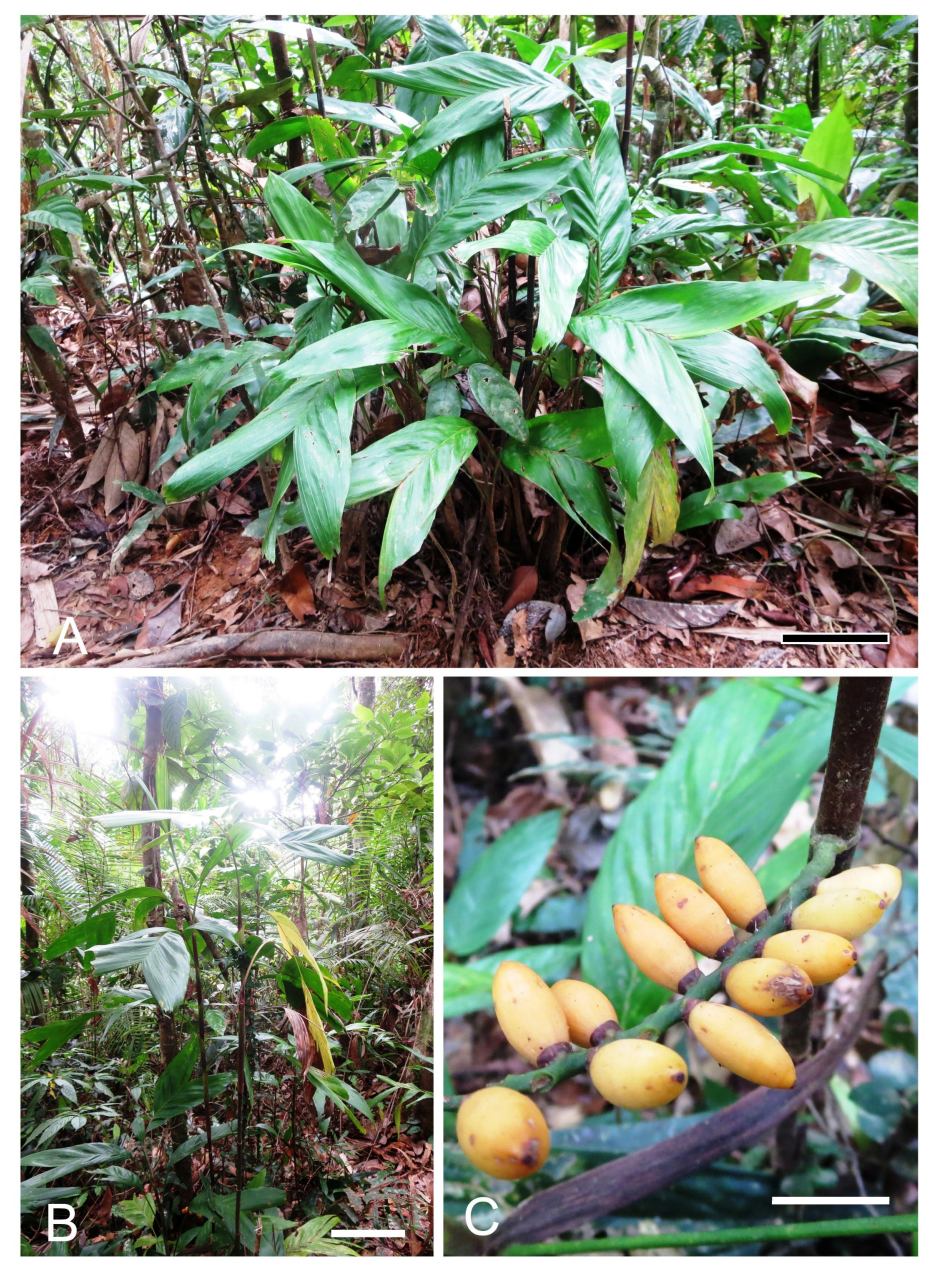

Figure 2. Pinanga lepidota at ca. $600 \mathrm{~m}$ elevation on $\mathrm{Mt}$ Mantalingahan, Palawan. A Juvenile plants with mostly entire leaves; B Plants with prominent slender stems and dissected leaves; C Infructescence with nearly mature fruits. E.L.R. Logatoc 20-0156 (LBC). Scale bars $A=10 \mathrm{~cm} ; B=25 \mathrm{~cm} ; C=15 \mathrm{~mm}$. Photos by Eugene L.R. Logatoc

\section{Key to species of the Modesta group of Philippine Pinanga}

1 Stem habit solitary $\ldots \ldots \ldots \ldots \ldots \ldots \ldots \ldots \ldots \ldots$

- Stem habit clustering $\ldots \ldots \ldots \ldots \ldots \ldots \ldots \ldots \ldots .3$

2 Leaflets grayish-brown underneath when dried, rachillae few (rarely more than 4$) \ldots \ldots \ldots \ldots \ldots \ldots \ldots \ldots \ldots \ldots$ $\ldots \ldots \ldots \ldots \ldots \ldots$ P. egregia Fernando (Luzon, Polillo) - Leaflets reddish-brown underneath when dried, rachillae much more (mostly more than 4)...... P. isabelensis Becc. (Luzon) 3 Floral triads arranged in 3 -series along rachillae ..........

P. heterophylla Becc. (Luzon, Rapu-Rapu, Negros) - Floral triads arranged distichously along rachillae .......4 4 Leaflets with whitish indumentum abaxially, fruits set much further apart along rachillae (to $1.5 \mathrm{~cm}) \ldots \ldots \ldots \ldots \ldots \ldots$ 
.......P. modesta Becc. (Bucas Grande, Mindanao, Basilan) - Leaflets without whitish indumentum abaxially, fruits set much closer along rachillae (typically to $0.5 \mathrm{~cm}$ ) . . . . . 5 5 Inflorescence much-branched, with 4-9 rachillae........

. . . . . . . P. gruezoi Adorador \& Fernando (Samar, Dinagat, Bucas Grande, Mindanao)

- Inflorescence spicate, with only 1 rachilla (very rarely more than 1) $\ldots \ldots \ldots \ldots \ldots \ldots \ldots \ldots \ldots \ldots \ldots$

6 Leaflets fresh-looking and herbaceous-textured, rachillae longer (7-14 cm long), fruit narrowly ovoid-ellipsoid attenuate to the base and often slightly curved, ripening from green to pink, then red to purplish red, fruiting perianth contracted at the

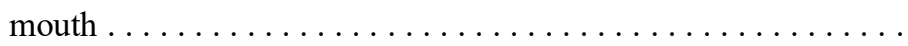
........ P. geonomiformis Becc. (Luzon, Polillo, Mindoro) - Leaflets dry-looking and tough-textured, rachillae shorter (up to $8 \mathrm{~cm}$ long), fruit broadly ovoid, typically ripening from green to yellow, fruiting perianth broadened at the mouth ......... . . . . . . . . . . . . . . . Pidota Rendle (Palawan)

\section{Notes on Bornean Palm Elements in Palawan}

The discovery of Pinanga lepidota on Palawan is not completely unexpected as the island is, biogeographically, often considered part of the Sunda continental shelf (Sundaland) and may have had a mid-Pleistocene connection to Borneo (Heaney 1986, Piper et al. 2011, Brown et al. 2013). Bornean botanical elements in Palawan were earlier noted by Merrill (1926a, b) and later by Philipson (1979) for Polyscias borneensis Philipson (Araliaceae), Wong (1998) for Dinochloa robusta S.Dransf. (Poaceae), Atkins et al. (2001) for Cyrtandra J.R. \& G.Forst. (Gesneriaceae), and Hoffman et al. (2003) for Phyllanthus balgooyi Petra Hoffm. \& A.J.M.Baker (Phyllanthaceae). For Arecaceae, there are 11 Bornean species, thus far, recorded in Palawan (but not elsewhere in the Philippines) (Dransfield 1980a, 1981, Fernando 1990a, Pelser et al. 2011, Saw 2012, Shahimi et al. 2019, Henderson 2020) viz.: Arenga brevipes Becc., A. distincta Mogea, Calamus caesius Blume, C. longipes Griff., C. marginatus (Blume) Mart. ex Walp., $C$. melanochaetes (Blume) Miq., Caryota mitis Lour., Korthalsia rigida Blume, K. robusta Blume, Licuala spinosa Wurmb, and Oncosperma tigillarium (Jack) Ridl. In addition, A. vidaliana occurs in Palawan and Balembangan Island (not strictly Bornean, but part of Sabah territory) (Merrill 1926b, Dransfield 1984). With very similar distribution pattern like A. vidaliana, Orania paraguanensis is in Palawan and Banguey Island, off the coast of Sabah (Merrill 1926b, Keim \& Dransfield 2012). Calamus malawaliensis J.Dransf. is also found in Palawan and Malawali Island, just south of Banguey (Fernando 1990a, BajaLapis 2010). The genus Adonidia Becc. includes the newly described A. dransfieldii K.M.Wong, J.B.Sugau, \& Y.W.Low from Sabah, Borneo (Wong et al. 2015) and A. merrillii (Becc.) Becc. from Palawan and the small island of Danjugan near Negros (Fernando 2011). There is yet one other Bornean palm, Salacca ramosiana Mogea, shared with Palawan and also with Tawi-Tawi (Mogea 1986, Fernando 1990a). However, there remain at least four Bornean palm genera that have yet to be found in Palawan (Kiew 1976, Dransfield 1982, Fernando 1983, 1990a), e.g. Eugeissona Griff., Iguanura Blume, Nenga H.Wendl \& Drude, and Plectocomiopsis Becc. Conversely, Heterospathe Scheff., a genus predominantly of the western Pacific and Papuasia, and now with 13 species in the Philippines (Fernando 1990b, Fernando \& Sotalbo 2001, Adorador 2019), including one species, $H$. dransfieldii Fernando in Palawan, has not been recorded yet in Borneo.

\section{Acknowledgements}

We thank Protected Area Superintendent Mildred Suza of the Mt Mantalingahan Protected Landscape (MMPL), CENROQuezon, and CENRO-Brooke's Point for their assistance; F. Escala III, B. Lumpon, R. Sendacan, and the local field guides from Ransang and Aribungos for their help and companionship. Permit to collect plant specimens for scientific research study was covered by Gratuitous Permit No. 2019-25 issued by the Palawan Council for Sustainable Development (PCSD). The recent field work in the MMPL was supported by the Forest Foundation Philippines (FFP) through the Pro-Seeds Development Association, Inc. ESF is grateful to the late $\mathrm{Mr}$ Leonardo L. Co for sharing his photos of herbarium specimen of Pinanga lepidota from Mt Mantalingahan in 2007.

\section{Literature Cited}

Adorador, J.T., 2019. Heterospathe fernandoi, a new palm (Areceae, Arecoideae, Arecaceae) from the Philippines. Phytotaxa, 401(2): 117-126.

Adorador, J.T., Z.D. Meneses \& E.S. Fernando, 2020. Pinanga gruezoi (Arecaceae), a new slender clustering palm from the Philippines with notes on an amended description of $P$. samarana. Phytotaxa, 429(2): 120-134.

Atkins, H., J. Preston \& Q.B. Cronk, 2001. A molecular test of Huxley's line: Cyrtandra (Gesneriaceae) in Borneo and Philippines. Biological Journal of the Linnean Society, 72: 143-159.

Baja-Lapis, A.C., 2010. A field guide to Philippine rattans. Asia Life Sciences Suppl. 5: 1-214.

Beccari, O., 1919. The palms of the Philippine Islands. Philippine Journal of Science (Botany), 14: 295-362. 
Brown, R.M., C.D. Siler, C.H. Oliveros, J.A. Esselstyn, A.C. Diesmos, P.A. Hosner, C.W. Linkem, A.J. Barley, J.R. Oaks, M.B. Sanguila, L.J. Welton, D.C. Blackburn, R.G. Moyle, A.T. Peterson \& A.C. Alcala, 2013. Evolutionary processes of diversification in a model island archipelago. Annual Review of Ecology and Systematics, 44: 411-435.

Dransfield, J., 1980a. On the identity of sika in Palawan, Philippines. Kalikasan, Philippine Journal of Biology, 9(1): 43-48.

Dransfield, J., 1980b. Systematic notes on Pinanga (Palmae) in Borneo. Kew Bulletin, 34(4): 769-788.

Dransfield, J., 1981. A synopsis of the genus Korthalsia (Palmae: Lepidocaryoideae). Kew Bulletin, 36(1): 163-194.

Dransfield, J., 1982. A reassessment of the genera Plectocomiopsis, Myrialepis and Bejaudia (Palmae: Lepidocaryoideae). Kew Bulletin, 37(2): 237-254.

Dransfield, J., 1984. The genus Areca (Palmae: Arecoideae) in Borneo. Kew Bulletin, 39(1): 1-22.

Dransfield, J., N.W. Uhl, C.B. Asmussen, W.J. Baker, M.M. Harley \& C.E. Lewis, 2008. Genera Palmarum: The Evolution and Classification of Palms. Royal Botanic Gardens, Kew, 732 pp.

Fernando, E.S., 1983. A revision of the genus Nenga. Principes, 27(2): 55-70.

Fernando, E.S., 1988. The mottled-leaved species of Pinanga in the Philippines. Principes, 32(4): 165-174.

Fernando, E.S., 1990a. A preliminary analysis of the palm flora of the Philippine Islands. Principes, 34(1): 28-45.

Fernando, E.S., 1990b. The genus Heterospathe (Palmae: Arecoideae) in the Philippines. Kew Bulletin, 45(2): 219 234.

Fernando, E.S., 1994. New species of Pinanga (Palmae: Arecoideae) from Luzon Island, Philippines. Kew Bulletin, 49(4): 775-784.

Fernando, E.S., 2011. Adonidia merrillii - a new wild population in the Philippines. PALMS, 55(2): 57-61.

Fernando, E.S. \& E.D. Sotalbo, 2001. A new species of Heterospathe with undivided leaves from the Philippines. PALMS, 45(3): 118-122.

Govaerts, R., J. Dransfield, S. Zona, D.R. Hodel \& A. Henderson, 2020. World Checklist of Arecaceae. Facilitated by the Royal Botanic Gardens, Kew. Available from: http://apps.kew. org/wcsp/ accessed 20 July 2020

Heaney, L.R., 1986. Zoogeographic evidence for middle and late Pleistocene land bridges to the Philippine Islands. Modern Quaternary Research in Southeast Asia, 9: 127144.

Henderson, A., 2020. A revision of Calamus (Arecaceae, Calamoideae, Calameae, Calaminae). Phytotaxa, 445(1):
001-656.

Hoffman, P., A.J.M. Baker, D.A. Madulid \& J. Proctor, 2003. Phyllanthus balgooyi (Euphorbiaceae s.1.), a new nickelhyperaccumulating species from Palawan and Sabah. Blumea, 48: 193-199.

Keim, A.P. \& J. Dransfield, 2012. A monograph of the genus Orania (Arecaceae: Oranieae). Kew Bulletin, 67(2): 127190.

Kiew, R., 1976. The genus Iguanura Bl. (Palmae). Gardens' Bulletin Singapore, 28: 191-226.

Matias, D.M. \& J. Tabangay, 2014. The role of conservation agreements in disaster risk reduction: the case of Mount Mantalingahan Protected Landscape (MMPL) in the Philippines. In: Murti, R. \& C. Buyck (eds.), Safe Havens: Protected Areas for Disaster Risk Reduction and Climate Change Adaptation. IUCN, Gland, Switzerland, Pp. 104115.

Merrill, E.D., 1922. An Enumeration of Philippine Flowering Plants. Vol. 1, Bureau of Printing, Manila.

Merrill, E.D., 1926a. An Enumeration of Philippine Flowering Plants. Vol. 4, Bureau of Printing, Manila.

Merrill, E.D., 1926b. The flora of Banguey Island. Philippine Journal of Science, 29(3): 341-429.

Mogea, J.P., 1986. A new species in the genus Salacca. Principes, 30(4): 161-164.

Pelser, P.B., J.F. Barcelona, \& D.L. Nickrent [eds.], 2011 onwards. Co's Digital Flora of the Philippines. http:// www.philippineplants.org [accessed 25.Jan.2020].

Philipson, W.R., 1979. Araliaceae-I. In: Steenis, C.G.G.J. van (ed.), Flora Malesiana, series I, Vol. 9, No. 1, Rijksherbarium, Leiden, pp. 1-105.

Piper, P.J., J. Ochoa, E.C. Robles, H. Lewis \& V. Paz, 2011. Palaeozoology of Palawan Island, Philippines. Quaternary International, 233: 142-158.

Rendle, A.B., 1901. Mr. Charles Hose's Bornean monocotyledons. Journal of Botany, 39: 173-179.

Saw, L.G., 2012. A revision of Licuala (Arecaceae, Coryphoideae) in Borneo. Kew Bulletin, 67(4): 577-654.

Shahimi, S., M. Conejero, C.J. Prychid, P.J. Rudall, J.A. Hawkins \& W.J. Baker, 2019. A taxonomic revision of the myrmecophilous species of the rattan genus Korthalsia (Arecaceae). Kew Bulletin, 74(4): 69.

Thiers, B., 2018 [continuously updated]. Index Herbariorum: A Global Directory of Public Herbaria and Associated Staff. New York Botanical Garden's Virtual Herbarium. Available from: http://sweetgum.nybg.org/ih/

Wong, K.M., 1998. Patterns of plant endemism and rarity in Borneo and the Malay Peninsula. In: Peng, C.I. \& P.P. Lowry (eds.), Rare, Threatened and Endangered Floras of 
Asia and the Pacific Rim. Academica Sinica Monograph Series No. 16, Institute of Botany, Taipei, Pp. 139-169.

Wong, K.M., J.B. Sugau \& Y.W. Low, 2015. Adonidia dransfieldii, a threatened new palm from Sabah, Borneo.

PALMS, 59(1): 5-14. 